\title{
EFFECT OF SHERMAN ACT ON FIXING PRICES OF PATENTED GOODS BY AGENCY LICENSING AGREEMENTS
}

FreQueNTLY posed in current anti-trust actions is the question of the scope of rights under letters patent. ${ }^{1}$ Since the monopoly conferred ly the patent statutes is at loggerheads with the competitive ideal of the Sherman Act, ${ }^{2}$ definition of the precise extent of the patent privilege is of the utmust importance. The line of demarcation between these two laws has been blurred by partial judicial acceptance of patent owners' contentions that restrictive patent license agreements are removed from the Sherman Act by the patent monopoly. Contending that such an immunity is unwarranted and that these restrictive agreements are in restraint of trade, the Government is currently attacking many patent licensing arrangements. ${ }^{3}$

\section{The General Electric Case}

The question of the scope of patent rights arises where a manufacturer of goods on which he holds patents designates his distributors as selling agents under patent licenses to vend. These arrangements have the purpose of reserving to manufacturers control over conditions under which patented goods are sold by distributors. Classic on the issue of validity of selling agencies under patent licenses is the case of United Statcs v. Gencral Electric Company." In 1926 General Electric owned three basic patents covering the manufacture of electric light bulbs and did sixty-nine percent of the business in such bulbs. In a suit under the Sherman Act instituted by the Government to challenge a scheme designed for controlling prices on the patented lullbs,

1. See United States v. Ethyl Gasoline Corp., 309 U. S. 436 (1940); United States v. Univis Lens Company, Inc., 10 U. S. L. WeEK 2216 (S. D. N. Y. 1941). A complaint raising many of the issues passed on by the Court in United States v. General Electric Co., 272 U. S. 476 (1926), has been filed by the Government against General Electric Company and other corporate defendants. A grand jury in Chicago has returned an indictment against the Wayne Pump Company and other corporate defendants charging misuse of patents in the manufacture and sale of computer pumps. 9 U. S. L. IVEEK 2454-55 (1941). Suits involving the scope of the patent privilege are likewise under way against Bausch \& Lomb Optical Company and the Hartford-Empire Company. See Havighurst, The Legal Status of Indistrial Control by Patent (1941) 35 Inx. L. Rev. 495,496 , n. 2 .

2. Mr. Justice Peckham in Bement v. National Harrow Co., 186 U. S. 70,91 (1902), stated: "The very object of these [patent] laws is monopoly, and the rule is, with few" exceptions, that any conditions which are not in their very nature illegal with regard to this kind of property . . . will be upheld by the courts."

"It was, of course, inevitable that there should be a clash between the patent statute which employs 'the language of complete monopoly' and the anti-trust laws, to which monopoly is anathema." Feuer, The Patent Monopoly and the Anti-Trust Laics (1933) 38 COL. L. REv. 1145, 1146.

3. Dep't of Justice, Public Release, Dec. 11, 1939, at 5.

4. 272 U. S. 476 (1926). 
the Court in the first aspect of the case considered the marketing plan adopted by General Electric. After unsuccessful efforts to sell the bulbs through independent retail outlets, General Electric designated some twenty-one thousand drug, hardware and other wholesale and retail stores as del credaro selling agents under patent license agreements to vend. ${ }^{5}$ In these agreements General Electric set prices for sales to consumers. The Government contended first, that the company could not use patent licenses as a device for controlling resale prices of goods purchased by retailers and, secondly, that the license agreements were contracts of sale instead of agency. The Court found that validity of the patent licenses to vend depended on whether the goods were sold or consigned. Implicitly relying on a well-accepted line of cases holding that a patentee by sale exhausts his control over the patented product, ${ }^{6}$ the Court adopted a major premise that patentees selling rather than consigning exceed their patent privilege by setting resale prices. On the other hand, the Court accepted without question the further premise that a principal may control the selling prices of its agents.

The Court then turned to what it considered the real issue in the first aspect of the General Electric case - existence of a genuine agency relationship. Examining various provisions of the agreements distributing elements of ownership and control, it concluded that a preponderance of the indicia attached to General Electric. Consequently, reasoned the Court, the relationship established was one of genuine agency, rather than one of sale masked" as agency. The bulbs belonged to General Electric, and the Company, of course, could set the prices of its own goods. ${ }^{7}$ In sustaining the agreements Chief Justice Taft thus regarded as irrelevant the fact that the goods involved were patented. ${ }^{8}$

5. General Electric sold some of its bulbs through its own sales offices to large consumers who could be readily reached. For more complexities of this comprehensive marketing plan, see United States v. General Electric Co., 272 U. S. 476, 481 ct scq. (1926) ; Brief for General Electric, p. 10 et seq., United States v. General Electric Co., 272 U. S. 476 (1926).

6. Bauer \& Cie. v. O'Donnell, 229 U. S. 1 (1913) ; Straus v. Victor Talking Machine Co., 243 U. S. 490 (1917) ; Boston Store v. American Gramophone Co., 246 U. S. 8 (1918).

7. United States v. General Electric Co., 272 U. S. 476, 481 ct seq. (1926). Virtuc v. Creamery Package Manufacturing Co., 227 U. S. 8 (1913) ; FTC v. Curtis Publishing Co., 260 U. S. 568 (1923) ; cf. Dr. Miles Medical Co. v. John D. Park \& Sons Co., 220 U. S. 373 (1911) ; Standard Fashion Co. v. Magrane-Houston Co., 258 U. S. 346 (1922). See annotations to United States v. Colgate \& Co., 250 U. S. 300, 7 A. L. R. 443, 449 (1919) and Doubleday, Doran \& Co. v. R. H. Macy \& Co., 269 N. Y. 272, 199 N. E. 409, 103 A. L. R. 1325, 1331 (1936).

8. In effect, Taft's argument used the agency contracts to bring the retail outlets within the scope of the business unit known as "General Electric." Although the Chief Justice stated that his sole reliance was on the genuineness of the agency, he resorted to the unlimited monopoly under the patent statutes to refute the Government's claim that the very size of the scheme rendered it illegal. 
In the second aspect of the Goncral Elcctric case the Court determined the validity of a patent license given by General Electric to Westinghouse and permitting manufacture and sale of electric light bulbs at prices set by the patentee. Sustaining the plan despite the Government's contention that General Electric could not use its power to license as a means of setting a competitor's prices, the Court held the terms of the patent license "normally and reasonably adapted to secure pecuniary reward for the patentee's monopoly." In taking this position the Court recognized that the price at which Westinghouse sold the bulbs it manufactured directly affected the income General Electric received from its sales. The Court thus dismissed the suit against General Electric. Both phases of the decision have become landmarks in anti-trust law; each of them has been invoked as a defense to the Government's charge in a pending suit under the Sherman det - Uniled States v. Masonite Corporation. ${ }^{10}$

\section{The Masonite Case}

Masonite Corporation owns process and product patents relating to hardboard, a type of artificial board now vitally important in the building industry and elsewhere. ${ }^{11}$ Hardboard is made by disintegrating waste wood chips or woody material and then converting the shredded mass into a hard, grainless, durable board by applying heat and pressure and using no other binding element than the natural lignins of the wood. Celotex Corporation and numerous other companies, manufacturers of a softer, weaker board used solely for insulation purposes, had preceded Masonite in the manufacture of artificial board. But after Masonite had begun to manufacture hardboard under its patents, Celotex introduced in 1930 a hardboard similar in many respects to MIasonite's. Masonite shortly instituted infringement proceedings.

When Masonite Corporation's patents were held valid and infringed in 1933, after prolonged litigation with Celotex, ${ }^{12}$ it faced the problem of enter-

9. 272 U. S. 476,490 (1926).

10. 40 F. Supp. 852 (S. D. N. Y. 1941). Appeal docketed with United States Supreme Court, 10 U. S. L. WeEK 3152 (1941). See 43 STAT. 933 (1925), 28 U. S. C. $\$ 345$ (1934).

11. It is used in the defense program as a substitute for some metal parts. 18 NEws WeEk, Sept. 15, 1941, at 41. Masonite is also licensed by the Insulite Company to use the latter's patents on hardboard. This license is exclusive even against the Insulite Company itself. Record, pp. 484, 492, United States v. Masconite Corp., 40 F. Supp. 852 (S. D. N. Y. 1941) (hereinafter cited as Record).

12. Masonite Corp. v. Celotex Co.,66 F. (2d) 451 (C. C. A. 3d, 1933) ; Masonite Corn. v. Celotex Co., 1 F. Supp. 494 (D. Dela. 1932). After the adverse decision by the Third Circuit Court of Appeals, Celotex petitioned for certiorari. While the chances that such a petition would be granted were, of course, slight, there was some possibility that either then, or later, after a conflict of circuits had been developed by Celotex, the Supreme 
ing the building materials field and obtaining nation-wide distribution facilities at a time of severe depression. In the building materials field, conservative, individual lumber retailers dominated the marketing process. Their acceptance of any new product was thus essential to manufacturers sceking extensive retail outlets. ${ }^{13}$ Celotex, then in receivership, had, however, the vast, established dealer organization required, but found itself at a competitive disadvantage as a result of the adverse decision. Rather than ordering from Celotex, dealers in the Celotex organization preferred to avail themselves of lower freight rates by ordering from a manufacturer who could give them a completely rounded line of goods, including hardboard, in one, full, mixed carlot shipment. Carlot rates were, of course, lower than those charged for shipments in less-than-carlot quantities. Thus Celotex, unable to ship hardboard in its mixed cars, faced the potential loss to Masonite of established dealer outlets. Solution of this impasse was a patent license agreement designating Celotex as the del credere selling agent for Masonite's hardboard. Masonite later made similar contracts with other large manufacturers of building materials possessing established retailer outlets. ${ }^{14}$ The agreements enabled Masonite to manufacture all hardboard in its plant and set the prices and terms of resale in contracts between agent-distributors and dealers.

In suing to enjoin continuing violation of the Sherman Act by means of these agency contracts, the Government raised questions fundamental to the nature of patent grants and the right to set distributors' prices by means of the agency device. The complaint first advanced the orthodox contention that the contractual agreements did not establish 'a bona fide agency relationship. The Government applied conventional agency criteria in its analysis of this point - distribution of incidents of ownership, Masonite's control over actions of its agents, and authority of the agents to bind Masonite as their principal. ${ }^{15}$ Judged by these tests, at least the first two of the three sets of agreements, those of 1933 and 1936, having many of the characteristics of sale rather than agency, might clearly have been differentiated on a factual

Court would have taken jurisdiction. That Court has displayed a greater tendency to hold patents invalid than have the lower courts. Record, Appendix, p. 7. But the day before the Court passed on the petition for certiorari, the license agreement between Celotex and Masonite was consummated and the petition for certiorari was withdrawn. Record, pp. 94, 253.

13. ". . . the most conservative member of their conservative industry, the lumber dealer." (Feb. 1939) 19 Fortune, 80, 82. Typical of the marketing in the entire builking materials field is the system of distribution by the manufacturers through their own established retail outlets, usually snall lumber dealers, numbering in some cases up to the thousands. Ibid.

14. Certain-Teed Products Corporation, Johns-Manville Sales Corporation, Insulite Company, Flintkote Company, National Gypsum Company, Wood Conversion Company, Armstrong Cork Company, and Dant \& Russell, Inc.

15. The use of the term "agent" carries no connotation that distributors necessarily are bona fide agents in the legal sense. 
basis from those approved in the General Elcctric case. ${ }^{16}$ The District Court, deciding in favor of defendants, recognized differences but nevertheless found the agreements to be contracts of agency rather than of sale and involed the doctrine of the General Electric case as precedent for sustaining them. Changes in the third set of agreements, made in 1941 after the Government had instituted suit and admittedly impelled by the pending action, placed more of the incidents of ownership on Masonite, thus bringing relationship between manufacturer and distributor more in line with that of the Gencral Electric case. ${ }^{17}$

\section{Agency Licensing Agreements}

In determining the validity of consignment contracts against an attack in the name of the public interest, it seems artificial to employ conventional agency criteria shaped in reference to private law. ${ }^{18}$ The Sherman Act bans

16. Masonite's original contracts were made in 1933, and modified in 1936 and again in $19 \div 1$. The court considered only the 1933 agreenent since it presented the ease most favorable to the Government.

General Electric in its agreements controlled the quantity and kind of stock to bs kept on hand by the agents; Masonite made no such provision in its 1933 agreement. Likewise General Electric could order return of stock at any time; Masonite cuuld only recall stock from its agents in special circunstances. With respect to indicia of ownership, Masonite's distributors were to pay the freight on the consigned goods, earry insurance on them, pay taxes in respect of sale, might not use Mlasonite's trademarls, and had to pay for the goods consigned by advancing one-half of the price of the hardboard within a limited time even though the goods had not yet been sold. The terms of payment were altered in the 1936 agreement. General Electric, in contrast, paid freight, taxes, and insurance, put its own trade-mark on the goods, and required no payment until the goods had been sold, but did require that the agent pay for any lost or broken stusk. Finally, the distributors in the Masonite case agreed to save Masonite harnless from any tortious actions by third parties arising out of sale of hardboard. United States v. Mfasonite Corp., 40 F. Supp. 852, 855 et seq. (S. D. N. Y. 1941), Kecord, p. 493 et seq.

17. Lnder the 1941 agreements, Masonite paid the cost of insurance and tases, advanced the agent the freight on the consigned goods, and used its own tradenzarl: on all hardboard sold by the agents. Payment was to be made by the agent only after the hardboard had been sold.

Counsel for the Government argued, quite independently of the details of the agreements, that the distributors were essentially independent cuntractors with independent callings, control of their own selling policies, advertising and salesnen. The Distritt Court denied that this constituted any basis for differentiation. Record, p. 499.

18. The question arises between private litigants when a dealer holding agency gouls becomes bankrupt and the manufacturer, rather than be relegated to a general claim, attempts to obtain a return of the specific goods [Miller Rubber Co. v. Citizens' Trust and Savings Bank, 233 Fed. 488 (C. C. A. 9th, 1916)] and in determining a liahility for taxes on consigned goods [Ferry \& Co. v. Hall, 18S Ala. 178, of So. 104 (1914)]. See Stefrex, Cases on Agevicy (1933) 65; Klaus, Sale, Alency and Price Mluintchance; II (1928) 28 CoL. L. REv. 441, it seq. "Whether a producer of goods should be permitted to fix ... the price at which the purchaser may resell them ... is an cconomic question. To decide it wisely it is necessary to consider the relevant facts, industrial and 
all contracts in restraint of trade and makes no exception for contracts of agency. ${ }^{19}$ Introducing into this general axiom of public law an exception based on permutations of incidents of ownership, control and responsibility, which were shaped to adjudicate rights of private litigants, ${ }^{20}$ allows a private agreement to thwart public interest as expressed in the Sherman Act. Theoretically, a principal and agent can achieve any adjustment of these matters by simply providing a greater or less compensation for the agent depending on the amount of responsibility and degree of risk he asstumes. ${ }^{\text {at }}$ Whether effect is given to the public's interest in maintaining competition is made to depend, therefore, on the irrelevant factor of the private decision of two parties concerning the distribution of risk bearing and compensation between them. ${ }^{22}$

Frequently, the manufacturer prefers, consignment rather than sale since it gives him some degree of control over goods after they have passed out of his hands. And, generally speaking, the stronger the bargaining position of the manufacturer, the greater the possibility that he can force an agrecment of agency on his dealers. ${ }^{23}$ When such competitive strength is combined with the ability to fix prices in disregard of the spirit of the Sherman Act, the hand of a competitor who already has a substantial advantage is greatly strengthened.

Since Masonite did not own the marketing facilities from its factory to the consumer, it perforce made use of regular channels of marketing to reach the ultimate buyer. It was for the use of channels already established by its agents that Masonite bargained in the contracts with its distributoragents. As soon, therefore, as Masonite had placed its goods in the market by turning them over to the distributors who in turn passed them on to dealers, the public acquired its usual interest in seeing that competition was maintained in goods moving in regular channels of trade. Masonite should not have been able to defeat this interest through an ability, by virtue of competitive advantage, to appoint as agents business units constituting an essential link in this marketing chain.

commercial, rather than established legal principles." Brandeis, J., concurring in Boston Store v. American Gramophone Co., 246 U. S. 8, 27 (1918).

19. "Every contract, combination in the form of trust or otherwise, or conspiracy, in restraint of trade or commerce among the several states, or with forcign nations, is hereby declared to be illegal . .." 26 Srat. 209 (1890), 15 U. S. C. \$1 (1934).

20. Some idea of the possible variations in distribution of the incidents of owncrship and control in sales and agency agreements may be gained from the annotation to Ferry v. Hall, 188 Ala. 178, 66 So. 104, 1917B L. R. A. 626 (1914). See also 1 Mecrem, Tire Law of Sale of Personal Property (1901) 38 et seq.

21. See Sturm v. Boker, 150 U. S. 312, 330 (1893).

22. See Klaus, Sale, Agency and Price Maintenance (1928) 28 Cot. L. REv. 312 and 441; Comment (1927) 27 Cor. L. REv. 567.

23. See Klaus, supra note 22 , at 464 . 
Thus it may well be held that a claim of agency is no defense to a charge of price fixing in restraint of trade brought under the Sherman Act.24 Nor does this seem to be an unwarranted result. ${ }^{25}$ Thile it is desirable not to interfere with the power to set sale prices in many types of agency agreements, elimination of agency as a defense to a charge of price fixing will not interfere with normal consignment transactions. In all such cases, the question then becomes the usual query in anti-trust cases under Section One of the Sherman Act: Is the contract or agreement a restraint of trale? On this basis, most normal agency transactions may be sustained. ${ }^{20}$ Iad this procedure been adopted in the Masonite case, though the price fixing agreements there were undoubtedly a restraint of trade, there would still remain, after the assumption of the bona fide character of the agency contracts, the subsequently considered problem of determining the effect of the patent license to vend.

An alternative to complete elimination of agency as a defense to a charge of price fixing is possible even after recognition of defects in conventional consignment criteria. This position the Government adopted in attempting to distinguish the Masonite case from United States a. Gencral Elcctric Company. On this level of attack the Government, conceding for the moment the existence of a bona fide agency relationship, contended that, nevertheless, the Masonite setup was outside the scope of the Gencral Elcctric case because the agreements there involved were virtical in the chain of distribution ${ }^{27}$ whereas the Masonite agreements were horizontal. In the earlier case there was little or no possible area of competition between General Electric and its distributors; General Electric sold only to large consumers while its agents, chiefly small retail stores, generally sold to small buyers. ${ }^{23}$ Masonite

24. With the exception of the patent license agreement fixing prices, and up until the passage of the Miller-Tydings Act [50 Stat. 693 (1937), 15 U. S. C. $\$ 1$ (Suln. 1939)], the courts had invalidated almost every positive effort by the seller to fi: resale prices, except the agency arrangement. 2 Prentice-Hall 1941 Fed. Trade and Industry Serv. II 96,051. See also, Comment (1940) $2 S$ Calif. L. Rev. 477; Legis. (1937) 51 HARv. L. Kev. 336, n. 4; McLaughlin, Fair Trade Acts (1938) 80 U. of F.. L. Rev. 803. Selignian and Lote, Price Cutting and Price Minintenanice (1932) 460 el seq. The latest authoritative statement expressly says that agreements to fix prices in interstate commerce are unlawiul per se under the Sherman Act. See United States v. SoconyVacuum Oil Co., Inc., 310 U. S. 150, 218 (1940).

25. Especially since the Miller-Tydings Amendment sanctions a method for accomplishing many of the results achieved by the agency arrangement. 50 Sr..7. 693 (1937), 15 U. S. C. $\$ 1$ (Supp. 1939).

26. An owner of a house who appoints an agent to sell it and sets the price of sale would not be illegally restraining competition.

27. This refers to the agency agreement with the distributors, and not to the patent license with Westinghouse, a horizontal agreement.

28. The larger agent-distributors in the General Electric case did malie delivery from their stocks to some big customers, but the contracts were signed between General Electric and the customer and the terms were the same as in the other direct sales by 
and its agents, however, sold in the same field and admittedly competed ${ }^{20}$ openly for each other's dealers. ${ }^{30}$ Each company designated by Masonite as an agent occupied relatively the same position in the chain of distribution as did Masonite itself. Each was a manufacturer who needed hardboard to supplement the line of building products it manufactured and distributed to its dealers. Consequently, by way of contrast with the agreements in the General Electric case, those made by Masonite effectually removed the most important factor in competition between Masonite and its distributors, i.c., the element of price.

Although the District Court seemingly gave this argument little attention, it might be accepted as basis for judgment. Prior to passage of state fair trade acts $^{31}$ and the Miller-Tydings Amendment ${ }^{32}$ to the Sherman Act, courts, generally speaking, had outlawed efforts of members of the competitive market to fix prices of sale or resale. ${ }^{33}$ In the realm of interstate commerce, activity of this kind fell afoul of the Sherman Act $^{34}$ except in a few situations such as those involving patent licenses to manufacture and sell. But as a result of the Miller-Tydings Amendment part of this general interdiction against price fixing was lifted. The Amendment granted inmunity from the Sherman Act to agreements made for resale price maintenance of branded goods where such price fixing had been legalized by state legislation. ${ }^{35}$ It legalized setting of resale prices by a manufacturer for his branded goods in the hands of a distributor. But it expressly withheld this

General Electric to large customers. Brief for General Electric, p. 10, United States $v_{\text {, }}$ General Electric Co., 272 U. S. 476 (1926).

As indicated, Taft's argument extended General Electric's corporate boundaries to include retail outlets. See note 8 supra. Since these agreements regulate the flow of goods from manufacturer to consumer, they are admirably illustrative of vertical arrangements.

29. The competition was largely in the form of offering to the dealer the services of the distributors in helping him to resell his goods.

30. Record, p. 173.

31. See Old Dearborn Distributing Co. v. Seagram-Distillers Corp., 299 U. S. 183 (1936) ; The Pep Boys, Manny, Moe \& Jack of Calif., Inc. v. Pyroil Sales Co., Inc., 299 U. S. 198 (1936) ; Legis. The Fair Trade Lanes: State Validation of Resale Pricc Maintenance (1936) 36 CoL. L. Rev. 293; Comment, Resale Price IVaintencence: The Fair Trade Acts in Operation (1938) 52 HARv. L. Rev. 284.

32. 50 StaT. 693 (1937), 15 U. S. C. §1 (Supp. 1939).

33. See note 24 sitpra.

34. United States v. Trans-Missouri Freight Association, 166 U. S. 290 (1897); Addyston Pipe \& Steel Co. v. United States, 175 U. S. 211 (1899); Dr. Miles Medical Co. v. John D. Park \& Sons Co., 220 U. S. 373 (1911) ; Standard Sanitary Manufacturing Co. v. United States, 226 U. S. 20 (1912); United States v. Trenton Potterics Co., 273 U. S. 392 (1927); United States v. Socony-Vacuum Oil Co., Inc., 310 U. S. 150 (1940). See Peppin, Price-Fixing Agrecments Under the Sherman Anli-Trust Law (1940) 28 CALIf. L. Rev. 667, 693.

35. All but four of states have passed such legislation. Comment (1940) 28 CAuny. L. REv. $477,479$. 
immunity from price fixing agreements between manufacturers, or between wholesalers, or between retailers, i.c., horizontal agreements. ${ }^{3 \mathrm{~B}}$ Thus, in setting up a criterion for determining the validity of Misonite's agreements with its agents the distinction between horizontal and vertical price fixing agreements already present in the Sherman Act and applicable to branded goods offers by analogy a valid basis for testing a different form of agreement but one whose general purpose is the same, namely, that of fixing prices. The type of agreements in the Miasonitc case among manufacturerdistributors is regarded with more hostility by the law than the type in the General Electric case between manufacturer and dealer, ${ }^{37}$ and the cases might well be distinguished on this basis. Acceptance of the suggested distinction simply results in carrying over the horizontal-vertical criterion from the field of resale price fixing in branded goods to the field of price fixing by means of the agency device - also essentially a form of setting "resale" prices. ${ }^{38}$

As evidence of the significance of this difference, the Government pointed out that General Electric in its agreements with agents stipulated no sale price for electric light bulbs. Absence of competition between principal and agent made price stipulations unnecessary. In the Masonite arrangement, on the other hand, Masonite bound itself to maintain the same price it set for its agents. ${ }^{39}$ It could change prices only after a certain period from the date of giving notice of proposed price modifications. Thus, in effect, MIasonite established an open filing system of prices for the industry, providing an effectual limitation on its own competitive power..$^{20}$ Masonite's limitation of its own prices was necessary to prevent it from selling below the prices fixed by contract for its agents. This particular provision thus evidenced the fact that Masonite's arrangement, in contrast with that of General Electric,

36. This proviso was inserted to cure the objections of the Administration to the Bill. 81 Cong. Rec. 7496 (1937). See Pazen v. Silver Rod Stores, Inc., 10 U. S. L. Wees 2267 (N. J. Ct. Err. and App. 1941) : Calvert Distillers Corp. v. Leland Vine and Liquor Stores, Inc., 2 Prentice-Hall $1941 \mathrm{Fed}$. Trade and Industry Serv. $\lceil 97,178$. (X. Y. Sup. Ct, Spec. Term, 1941) ; Rayess v. The Lane Drug Co., 2 Prentice-Hall 1941 Fed. Trade and Industry Serv. $\Uparrow 97,179$ (Ohio Sup. Ct. 1941).

37. It would seem that General Electric's agreements with its dealers were designed to accomplish the purpose now sanctioned by the Miller-Tydings Amendment, i.c., the prevention of price cutting by the dealers in the trade-marked electric light bulbs. See Klaus, supra note 22, at $312 \mathrm{ff}$.

38. The adoption of this distinction, however, has an objection from a policy point of view in that the Department of Justice has recommended to TNEC the repeal of the Miller-Tydings Act. 9 U. S. L. WEEK 2486 (1941). The TNEC has embodied this recommendation in its final report. Sex. Doc. No. 35, 77th Cong., 1st Sess. (1941).

39. In all the agreements it was necessary for Masonite to give notice tefore it changed its prices. In the 1933 and 1936 agreements it was expressly stated that Maconitc would sell at the same prices which it fixed for its agents. Record, p. 487.

40. Thus, while Masonite might lower prices on hardboard, it could do so only after giving notice. Prices for all the distributors, then, would move up and down uniformly. 
eliminated an area of price competition between principal and agent. Had this horizontal-vertical modification of the conventional agency doctrine been adopted by the Court in the Masonite case, there would still remain the question of the effect of the patent license to vend, just as that problem must be considered after complete elimination of the agency defense.

\section{Patent Licenses to Vend}

The contracts appointing Masonite's agents were labelled as patent license agreements to sell. As found by the Supreme Court in considering the first phase of the General Electric case, the existence of a patent added nothing to the validity of the agreements under conventional treatment of the agency problem. ${ }^{41}$ Validity of both factors in General Electric's contracts, agency and patent license to vend, depended upon the same determination, namely, whether the transaction was sale or consignment. But, if the Government in the Masonite case grants the bona fide character of the agencies and then seeks to avoid their hitherto validating effect on price fixing agreements by one of the alternatives already mentioned, it becomes necessary to consider the scope of rights under the patent licenses to vend. Prohibition against resale price maintenance through patent license agreements ${ }^{42}$ is no longer operative since, by the Government's admission, no original sale to distributors occurs.

The patent statute grants to the patentee exclusive rights to make, vend and use his patented invention for seventeen years ${ }^{43}$ and provides that every patent or any interest therein shall be assignable by the patentee. ${ }^{44}$ Courts, reasoning that the patentee has the larger rights of suppressing his invention or excluding others from using it, concluded that the patentee must have the lesser right to license others to make, use or vend the patented product on any conditions he saw fit to impose. ${ }^{45}$ This logical approach if applied in all cases would have extended the patentee's immunity to what-

41. United States v. General Electric Co., 272 U. S. 476, 488 (1926). But sce note 8 supra.

42. See cases cited note 6 supra.

43. Rev. Stat. $\$ 4884$ (1875), 35 U. S. C. $\$ 40$ (1934).

44. Rev. Stat. $\$ 4898$ (1875), 35 U. S. C. $\$ 47$ (1934).

45. Henry v. A. B. Dick Co., 224 U. S. 1, 35 (1912). Cf. Motion Picture Patents Co. v. Universal Film Manufacturing Co., 243 U. S. 502, 514, 518 (1917). The courts have moved away from express adherence to this simple, logic-chopping conception. Sec Havighurst, The Legal Status of Industrial Control by Patents (1941) 35 ILL. L. Rev, 405, 502. But see Holmes, J., dissenting in Motion Picture Patents Co. v. Universal Film Manufacturing Co., supra at 520; Western Electric Co. v. General Talking Pictures Corp., 305 U. S. 124; 304 U. S. 175 (1938). While the courts do not expressly follow this notion, it would still seem to be inherent in decisions granting to the restrictive con* ditions in patent licenses immunity from the Sherman Act possessed by the patent mo nopoly. And it finds expression in the use of infringement proceedings to enforce restrictive licenses. See Western Electric Co. v. General Talking Pictures Corp., supra. 
ever restrictive agreements he chose to include in his license. But where the patentee sought to maintain resale prices or require use of an unpatented product as a condition of granting a license under the patent, courts have refused to follow the implications of this doctrine. ${ }^{\text {so }}$ Other restrictions, however, have been approved by the courts. ${ }^{47^{\circ}}$ To evaluate this method of approach and determine the proper scope of rights granted under letters patent, reference must be had to the basic function of the patent privilege.4s

Patents do not give patentees the rights to make, vend or use their inventions. A patentee already has these rights as part of his property in the article. The patent adds to these existing rights the privilege of making them exclusive by resort to infringement proceedings. ${ }^{49}$ In this limited sense, the patentee may be said to have a monopoly. The patentee may assign his exclusive right to others and with it the right to institute infringement proceedings; or he may grant a mere license, that is, permission to make, vend or use the patented good with a waiver of the right to sue. But the fact that the patentee has the privilege of refusing to license does not necessarily mean that he may restrict a licensee to limited use, as, for example, resale at a fixed price. The patentee may exclude all others and maintain his monopoly, but when he chooses by contract to license others to enter the protected realm, his contract should be enforced like any other, by an action on the contract, not by an infringement proceeding. ${ }^{50}$ And it should also be subject to all limitations of general contract law. ${ }^{51}$ The remedy available to a patentee against his licensee should not be the same as that available against an infringer. When licenses are used to establish combinations in

46. See note 6 supra and Carbice Corp. of America v. American Patents Develupment Corp., 283 U. S. 27 (1931).

47. Price restriction in license to make and vend: United States v. General Electric, 272 U. S. 476 (1926), Bement v. National Harrow Co., $18 \sigma$ U. S. 70 (1902) ; restriction to a certain market: General Talking Pictures Corp. v. Western Electric Co, 305 U. S. 124 (1938); restrictions of production of patented gouds by a licensce: Rubber Tire Wheel Co. v. Milwaukee Rubber Works Co., 154 Fed. 358 (C. C. A. 7th, 1907). Restrictions can also be applied to patented machines and their use. See Havighurst, suspro. note 45, at 513. See also, MicCormack, Restrictize Patent Licenses and Restraint of Trade, (1931) 31 CoL. L. Kev. 743; Comment (193S) 52 Harv. L. Rev. 308.

48. Concerning the patent, the Constitution states merely, "The Congress shall have power, to promote the progress of science and useful arts, by sceuring for limited timss to authors and inventors the exclusive right to their respective writings and discuseries;"

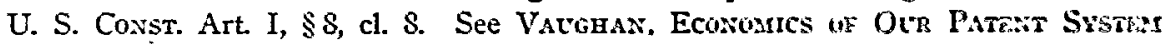
(1925).

49. Motion Picture Patents Co. v. Universal Film Manufacturing Ciu, 243 U. S. $502,510(1917)$.

50. Cf. Western Electric Co. v. Talking Pictures Curp. 345 U. S. 124 (1433).

51. Section three of the Clayton Act prohibits tying clauses, requiring that a competitor's goods shall not be used, in contracts of lease or sale where the effect of such clause is substantially to lessen competition. The sectim is made expressly amplicable to all goods whether patented or unpatented. 38 St.1T. 730 (1914), 15 U. S. C. $\$ 14$ (1934). 
restraint of trade, they are not inherently justified by virtte of the patent grant. Immunizing these agreements from the Sherman Act enlarges what originally was the right to exclusive property in the article into an absolute right to exemption even from competitive norms enunciated by Congress, ${ }^{\text {ta }}$ Consequently, in the light of this analysis and the prior analysis of the defense of agency, Masonite should not be able to advance its patent license to vend as justification of its price fixing activities. ${ }^{\text {(3 }}$

The Supreme Court, while it has on occasion recognized the validity of this argument, ${ }^{54}$ has rarely, if ever, adhered to it. It has rather made tise of different formulae of legality depending upon the particular need to be met. ${ }^{55}$ One criterion is that adopted by Chief Justice Taft in the Gencrul Electric case: the patentee who has granted a license to manufacture, use and sell may attach restrictive conditions to his license if "the conditions of sale are normally and reasonably adapted to secure a pecuniary reward for the patentee's monopoly." 50 That not all conditions in the license yielding pecuniary reward to the patentee are "normal and reasonable" has already been demonstrated. ${ }^{57}$ Chief Justice Taft in laying down the rule applied it strictly to the case of patentees who had granted licenses to manufacture, use and sell. Whether it likewise applies where the license is merely one to sell, as in the Masonite case, is open to question. ${ }^{58}$ If it is applied, it becomes

52. The conflict between patent statute and Sherman Act resulted in holdings by some courts that the Act was not intended to apply to agreements involving patented goods. See Bement v. National Harrow Co., 186 U. S. 70, 92 (1902).

53. Another clause in the agreement reserved to Masonite the exclusive right to sell hardboard in the industrial market. Restrictive conditions of this type were validated in Western Electric Co. v. General Talking Pictures Corp., 305 U. S. 124 (1938). In addition, the Government questioned an exclusive patent licensing agrcement giving Masonite the right to use the patents of the Insulite Company relating to hardboard. In Standard Oil Co. v. United States, 283 U. S. 163 (1931), it was held that such agrecments would be a violation of the Sherman Act if used to restrain trade. For a thorough inquiry into cross-licensing and pooling of patents, see Hearings Before House Commit= tee on Patents on H. R. 4523, 74th Cong., 2d Sess. (1936).

54. Motion Picture Patents Co. v. Universal Film Manufacturing Co., 243 U. S. 502 (1917).

55. Thus the patentee may not extend the scope of his monopoly to include unpatented goods. Carbice Corp. of America v. American Patents Development Corp., 283 U. S. 27 (1931). Or the patentee may grant a license to manufacture and sell conditioned on the maintenance of a sale price since such a condition is reasonably adapted to secure the patentee's pecuniary reward. United States v. General Electric Co., 272 U. S. 476 (1926). And the patentee may not extend his control over the patented goods in the hands of a purchaser since he exhausts the patent monopoly by the sale. Ethyl Gasoline Corp. v. United States, 309 U. S. 436 (1940).

56. See note 9 supra.

57. See note 6 stipra.

58. That "sell" is not interchangeable with "make, use and sell" can be scen from the fact that the doctrine of Bauer \& Cie. v. O'Donnell, 229 U. S. 1 (1913), forbids the setting of price in a license to sell where title to the patented good has passed to the licensee. Agency is needed to validate price fixing by such a license by keeping title in 
necessary to determine the reasonableness of the particular license restrictions used. The ground for holding that restrictions in the General Electric license to Westinghouse were reasonable was that the prices at which the latter might sell directly affected prices which the former could command for its product. Since General Electric had chosen to exploit its patents by selling the patented article itself, therefore, reasoned the Court, this restriction was necessary to secure to the patentee financial reward in the way he had chosen to obtain it. ${ }^{59}$ Under the Masonite agreements, however, the Company derives its chief financial return in the non-industrial field from money collected from del credere agents according to a fixed schedule of prices for hardboard. As far as this pecuniary reward is concerned, not only does the price restriction directly benefit the agent-distributors; it also indirectly benefits Masonite by keeping distributors' prices uniformly high. Thus Masonite can ask correspondingly high prices from them. On the other hand, MIasonite obtains part of its pecuniary reward from sales directly to dealers in competition with the agents, and this income is immediately affected by Masonite's inability to set the sale price for distributors. It thus seems, under the reasoning of the Supreme Court in the Goncral Elcctric case relative to what constitutes a reasonahle restriction, that Masonite's price fixing arrangement should be held to be reasonable.

More recently, in the case of United States v. Ethyl Gasoline Corporation, ${ }^{\text {co }}$ Mr. Justice, now Chief Justice, Stone stated that the patentee might grant licenses on any conditions except those further extending his monopoly. Just how this latest criterion of legality of patent license agreements bears on the Masonite situation, however, is not yet clear. ${ }^{.2}$

Undoubtedly, a major policy consideration in partial validation by courts of restrictive patent licensing agreements has been belief that these agreements were necessary to secure to the patentee his pecuniary reward. Such agreements, reasoned courts, implemented the statutory grant and further insured attainment of the objective of the Constitution - "to promote the

the patentee. Thus application of the Gencral Electric patent doctrine leads to the result that, having rejected the agency test of the legality of agreements setting prices, it would st:ll be necessary to determine the existence of a bona fide agency with conventional eriteria in order to test the legality of this particular type of price fixing agreement. Thu, all the previous objections to this method recur.

59. But it might equally well be held on this basis that resale price fising agrecments on patented goods are valid when the patentee is selling the goods in competition with his jobber-licensees. Yet Bauer \& Cie. v. O'Donnell, 229 U.S. 1 (1913), rules this out.

60. 309 U. S. 436 (1940). See also Interstate Circuit, Inc. v. United States, 306 U. S. 208 (1939): General Electric Co. v. Willey's Carbide Toul (in., 33 F. Supp. 969 (F. D. Mich. 1940).

61. United States v. Fthyl Gasoline Corp., 3109 U. S. 436,456 (1940).

62. The delimitation of the extent of the patent monopoly was not adianced by the Ethyl case. That decision merely applied already accepted doctrines. Havighurst, sufros note 45 , at 510, n. 60 . 
progress of science and useful arts . .."03 In the light of modern technological and economic conditions, however, it seems that striving after this goal, courts have lost sight of the fact that the patent grant is but an excepw tion, for a specific purpose, to the general norm of free, competitive enter" prise embodied in American law. Grant of the patent monopoly was designed to stimulate invention in order that the public might enjoy the fruits of inventive genius. $^{64}$ Restrictive patent conditions which raise prices, limit output, and restrict particular marketing areas to certain competitors thwart the objective of allowing the public to share fully in these fruits of invention and make the patent an instrument for escaping the competitive ideal in business relations.

In striking a balance between these two apparently conflicting aims, it must first be noted that modern invention is no longer primarily the result of efforts of the lone tinkerer. ${ }^{65}$ Statutory protection of the patent no longer furnishes the prime incentive to employees in large research laboratories; it mainly offers to corporate holders of patents a method of securing comlpensation for the long, expensive process of developing a new product. of Sale of the patented good by the corporation in a protected market undoubtedly offers the greatest possibility of financial recoupment. But this methocl lends itself to abuse in practice, and obstructs the public's full enjoyment of the patented article. Patent holders may secure moderate returns through royalties, a method not containing such possibilities of abuse yet giving him competitive advantage over licensees. ${ }^{67}$ In addition, many concerns today undertake research and development simply as a matter of maintaining their competitive positions. ${ }^{68}$ Technical progress from these sources does not depend

63. See note 48 supra. See also United States v. General Electric Co., 272 U. S. 476, 490; Bement v. National Harrow Co., 186 U. S. 70, 89 (1902).

64. See opinion of Douglas, J., in Cuno Engineering Corp. v. The Automatic Devices Corp., 10 U. S. L. WeEK 4005, 4006 (U. S. 1941).

65. "I do not say that the day of the individual inventor is gone, Mr. Chairman, but I think it is rapidly fading." Conway P. Coe, Commissioner of Patents. Hearings Bcfore House Connmittee on Patents on H. R. 4523, 74th Cong., 2d Sess. (1936) 1068.

66. Hearings before TNEC pursuant to P. R. 113, 75th Cong., 3d Sess. (1938) v. 1, $150-61$.

67. Masonite could have licensed agents to sell with no price restriction and with or without a fee. It could have licensed them to manufacture and sell on payment of royalties and fees. While the latter alternative was offered by Masonite, the royalty and fee were prohibitive. Profits derived from royalty payments are substantially less than those resulting from manufacture and sale by the patentee and his licensees in a protected market. See Havighurst, supra note 45, at $507 \mathrm{ff}$., 511. Competitors mily welcome a licensing program by the patentee which offers prospects of inducing a substantial part of the industry to accept price restrictions. Sce TNEC, op. cil. supra note 38 , at 36 .

68. Hamilton, TNEC Rep., Patents and FreE ENTERPRise, Monograph 31 (1941) 155. This is apparently characteristic of automobile manufacturing. See Hiarings Before TNEC Pursuant to P. R. 113, 75th Cong., 3d Sess. (1938) v. 1, 121-92. It applies chiefly to large, well established firms. A small company launched to develop 
on the stimulus of the prospect of speculative profits possible in a protected market.

Furthermore, the patent statute itself now pernits large corporations to use patents to establish non-competitive domains of their own. ${ }^{69}$ With the heavy capital investment necessary in most industries, a patent in an unexplored field gives the owner an immense advantage over all competitors. This he may reinforce with patents on both improvements and alternative processes until his permanent competitive advantage is virtually assured. ${ }^{\text {io }}$ Established in this protected position, a concern with sufficient resources to support a large research staff and provide necessary laboratory facilities can harness technological advance to maintain its corporate empire. Even if they can obtain capital requisite to launch their venture, small patent owners who later enter the field must face the threat of expensive, prolonged patent litigation often designed to harass and annoy. ${ }^{\mathbf{}}$ Increasing the privileges given corporate patent holders by the patent statute itself by adding the further competitive advantage of sales in markets protected by patent licenses excludes the operation of competition from another large segment of economic life. ${ }^{2}$ Nor may this extension of the non-competitive area be justified on the ground that it serves to stimulate invention.

\section{Supplemental Arguments for ilasonite}

The most obvious defense available to Masonite Corporation hinges on the General Electric case and others similar to it, for they have sustained the general type of marketing arrangement that Masonite adopted. The Corporation might with some justification contend that its agreements were

a new product requires more patent protection, in part, beeause of the necessity of attracting capital with the prospect of speculative returns. Id. at 445,461 . But designing the rule for this particular case opens the door to the above abuses.

69. Id. at c. VI and 158 et scq. For an inquiry into the use of patents in the glass container industry, see Hearings Before TNEC Pursuant to $P$. R. 113, 75th Cong., 3d Sess. (1938) v. 1, 194. See also TNEC REP., op. cit. supra note 38, at 36 el seq. "In 1936, about fifty years after the first Edison patents were taken out, practically the same interests still controlled approximately 93 per cent of the industry." Hearings Bcfore Houtse Committee on Patcnts an H. R. 4523, 74th Cong., 2d Sess. (1936) 567.

70. See Borkin, Patents and the New Trust Problem (1940) 7 l.wW Aan Co:strsm. ProB. 74, 76. United Shoe Machinery Company holds more than 6000 patents on the processes in its industry. See Hammion, op. cit. supra nute $6 \mathrm{~S}$, at 60.

71. Id. at 77. This would suggest the wisdom of procedural changes which would make litigation concerning patents more expeditious and less expensive. See Hnsuro:i, op. cit. supra note 68 , at 146,150, 167 ot siq. TNEC REP., op. cit. sipra note 38, at 37 (suggesting a single court of patent appeals to replace the present jurisdiction of the circuit courts of appeals).

72. The TNEC in its final report advocates Congressional adoption of a plan of compulsory licensing at reasonable rates for all patents. This would eliminate suppression of patents. In addition, licenses are to contain no restrictions as to amount, price of sale, purpose or manner of use, or as to geographical area. Id. at 36. 
made in reliance on these previous judicial decisions and that the principle of stare decisis demands that any present change, at least in definition of the scope of the patent privilege, must be made by the legislature. ${ }^{73}$ Masonite also argues that the 1933 agreement is valid because it was made when Celotex was in receivership in the federal district court. But any legalizing effect stemming from the receiver's approbation of the licensing contracts would vanish when the companies continued the arrangements after Celotex regained control of its affairs. ${ }^{74}$ As a further defense, Masonite introduced evidence of the reasonableness of its prices, but this would not seem to be material in view of the recent pronouncement by the Supreme Court. ${ }^{75}$

Another argument developed by the defense emphasizes the competitive necessity for the agreements adopted. It is pointed out that, when confronted by the problem of entering the building materials field as well as by the fact that its plant was operating at a fraction of capacity, Masonite took that course of action most feasible from an economic standpoint. By making the licensing agreements as it did, the Corporation attained the economies of mass production ${ }^{76}$ and, at the same time, achieved distribution facilities for its product. Furthermore, the contracts had a stabilizing effect on the industry because they removed the danger of cutthroat competition ${ }^{77}$ and diminished the incentive for distributors to infringe Masonite's patents. ${ }^{78}$ Thus a decision in favor of the Government in the Masonite case might place a premium on corporate size. Since they lack funds and established connections, new concerns like Masonite experience greater diffictilty in forcing entrances into industrial markets and recouping heavy developmental expenses than larger firms do. In addition, if the agency method of market control is invalidated by the Court in the Masonite case, smaller corporations will be at a disadvantage in adopting an alternative method of marketing control - assimilation of the retail outlets within their own corporate structures.

73. See note 72 supra.

74. United States v. Socony-Vacuum Oil Co., 310 U. S. 150, 227 (1940).

75. Id. at 218 .

76. The economic necessity for mass production and its attendant savings werc stressed at the trial. See Record, pp. 225, 226, 381. For the building naterials field as a whole, see ForTune, stipra note 12, at 124. Lack of mass production methods in the building materials field tends toward high prices.

77. When Masonite made its 1933 agreement it had before it the experience of the U. S. Gypsum Company, which had introduced sheet rock at $\$ 38$ per thousand feet in 1915 and watched the price decline to $\$ 10$ under cutthroat competition and in sixtcen years never spent less than $\$ 225,000$ a year fighting patent suits. Plaintiff's exhibit 16 for Identification, Record, Appendix, pp. 29, 30. See also Record, p. 397.

78. Masonite did not attempt to draw agreements which would prevent its agents from developing an artificial board not infringing the hardboard patents. Several of the licensee companies spent a great deal of time and money in attempts to perfect a process so that they might take advantage of the cancellation clause in the agreements permitting them to do their own manufacturing. Record, p. $253 \mathrm{ff}$. 